\title{
Core Criminal Law Provisions in the United Nations Convention Against Corruption
}

\author{
Michael Kubiciel* \\ Senior Research Assistant, University of Regensburg, Germany
}

\begin{abstract}
With the adoption of the UNCAC in 2003, the international legal development in the fight against corruption has reached its peak. Now the convention has to be filled with life. This is the task of national law-makers, law enforcement bodies and courts. They all need substantial information concerning the content of the convention's articles. Unfortunately, an offical or semi-official commentary to the UNCAC does not exist. This study aims at filling that gap by providing substanial information for the core criminal law provisions "bribery of public offical" and "active bribery of foreign public officials". To this end, the study reveals cross-relations between the UNCAC and international conventions whose articles have been used as examples for the legal design of the UNCAC. Since several of the preceding conventions are accompanied by official commentaries or explanatory reports, these documents also offer a deep insight into the UNCAC.
\end{abstract}

\section{Keywords}

Corruption, bribery, United Nations Convention Against Corruption, international legal development

\section{Introduction}

Corruption flourishes in the shadow and often feeds the powerful. ${ }^{1}$ Many states hence ignored corruption at home for a long time while others even promoted bribery of national companies abroad. ${ }^{2}$ In the 1990 s, however, the political and

*) Dr. Michael Kubiciel has counselled the United Nations Office on Drugs and Crimes in view of the implementation of the United Nations Convention Against Corruption. The text however reflects his personal opinion.

1) For the common definition according to which corruption is the abuse of public function for private benefit, see A. Doig, R. Theobald, Corruption and Democratization (London/Portland 2000) 3; V. Tanzi, 'Corruption Around the World', International Monetary Fund, Staff Papers (1998) 559, 564. For wider concepts covering corruptive acts in the private sector, see I. Carr, 'Fighting Corruption Through Regional and International Conventions: A Satisfactory Solution?', 15 European Journal of Crime, Criminal Law and Criminal Justice (2007) 121, 131-132; A. Eser, M. Kubiciel, Institutions Against Corruption (Baden-Baden 2005) 17-21. An illustrative list of corruptive acts includes Asian Development Bank (ed.), Anticorruption (Manila 1998) 11.

2) See B. Crutchfield George, K.A. Lacey, J. Birmele, 'On the Threshold of the Adoption of Global Antibribery Legislation. A Critical Analysis of Current Domestic and International Efforts Towards 
economic scaffold in which corruption could unfold changed radically: With the end of the Cold War, Western governments gave up their unconditional support for corrupt regimes in developing countries and increasingly demanded goodgovernance. ${ }^{3}$ Corruption was no longer part of an advisable political strategy; rather, it was identified as a crucial cause for global poverty. ${ }^{4}$ Economically, the increasing global competition led to rising prices for bribery in international procurement. ${ }^{5}$ More and more economic leaders thus agreed that the costs of corruption had become unacceptably high. ${ }^{6}$ Finally, many governments in developed nations came to regard transnational corruption as a danger for their own societies since growing global trade and international mergers facilitated the infection with the corruption-virus. ${ }^{7}$ As nations gathered at "the threshold of a global attack on corruption", ${ }^{8}$ international organizations provided them with legal weapons. In 1997, the "OECD Convention on Combating Bribery of Foreign Public Officials in International Business Transactions" was adopted as the first global convention against corruption. After the avalanche had been set off, the international development accelerated and broadened, yielding a multitude of legal instruments. ${ }^{9}$ The United Nations Convention Against Corruption (UNCAC) from 2003 marks the peak of this development.

the Reduction of Business Corruption', 32 Vanderbilt Journal of Transnational Law (1999) 1, 3-4. For the opinion in economic science according to which corruption can be a useful tool to promote business in complex bureaucracies, cf. N. Leff, 'Economic Development Through Bureaucratic Corruption', 3 American Behavioral Scientist (1964) 8, 9-12; J. S. Nye, 'Corruption and Political Development: A Cost-Benefit Analysis', 61 American Political Science Review (1967) 417-427. Also see J.H. Davis, J.A. Ruhe, 'Perceptions of Country Corruption: Antecedents and Outcomes', 43 Journal of Business Ethics (2003) 275, 276.

3) A. Doig, R. Theobald (supra note 1) 8-9.

4) See UNDP (ed.), Institutional Arrangements to Combat Corruption (Bangkok 2005) 3; R. Sandbrook,J. Oelbaum, 'Reforming Dysfunctional Institutions through Democratization?', 35 Journal of Modern African Studies, (1997) 603 et seqq.

5) Public officials in Africa, Asia or Latin America that once charged $10 \%$ of a contract value were put into a position in which they could demand $30 \%$ as side payment, see A. Doig, R. Theobald (supra note 1) 7; C. Hotchkiss, 'The Sleeping Dog Stirs: New Signs of Life in Efforts to End Corruption in International Business', 17 Journal of Public Policy \& Marketing (1998) 108, 110.

6) See for example the International Chamber of Commerce Rules of Conduct to Combat Extortion and Bribery in International Business Transactions from 1996; B. Crutchfield George, K.A. Lacey, J. Birmele, (supra note 2) 17; cf. as well J.H. Davis, A. Ruhe (supra note 4) 276.

7) R. Sanyal, 'Determinants of Bribery in International Business: The Cultural and Economic Factors', 59 Journal of Business Ethics (2005) 139. Particularly the economic and political integration in Europe brought about the danger that the incorporation of Eastern states infects the European Union with corruption.; cf. B. Crutchfield George, K.A. Lacey, J. Birmel, (supra note 2) 4, 24; W. Hetzer, 'Corruption and Integration - Does the Expansion of the European Union Represent a Risk Factor?', 12 European Journal of Crime, Criminal Law and Criminal Justice (2004) 301, 304 et. seqq.

8) B. Crutchfield George, K.A. Lacey, J. Birmele, (supra note 2) 46.

9) See the United Nations Office on Drugs and Crime (ed.), Compendium of International Legal Instruments on Corruption, 2nd edition (New York 2005), which includes 21 legal instruments. Moreover, many other institutions such as the World Bank, the International Monetary Fund, the 
The UNCAC includes preventive measures and provisions on international co-operation as well as an effective legal regime concerning money laundering and asset recovery. Its chapter on criminalization and law enforcement however is the heart of the UNCAC. While several articles such as the one on bribery in the private sector are non-mandatory provisions, states have to implement the provisions on bribery of national public officials (Article 15), active bribery of foreign public officials (Article 16 [1]), laundering of proceeds of crime (Article 23) and obstruction of justice (Article 25). Many nations thus have to complement their criminal codes, including those states which have already ratified preceding conventions, since the legal instruments against corruption diverge significantly. ${ }^{10}$

Whether national legislative acts are necessary or not, cannot be decided by comparing the wording of national law with the words of the convention as states have to comply not with the form but with the content of international law. Therefore, implementing the UNCAC requires substantive information concerning the meaning of its terms. Official documents however cannot provide that information, since the UNCAC has been adopted without a commentary or an explanatory report. ${ }^{11}$ This deficiency is a major obstacle for the legislative implementation of the UNCAC. Furthermore, it impedes the judicial transformation because national courts need orientation about the international legal standards which to follow can even be a duty of international ${ }^{12}$ and national ${ }^{13}$ law.

In order to enhance both the legislative and the judicial implementation of the UNCAC, this study analyzes the convention's core criminal law provisions: bribery of public officials and active bribery of foreign public officials. To this end, we will reveal cross-relations between the UNCAC and international conventions whose articles have been used as examples for the legal design of the UNCAC.

Asian Development Bank, and the International Chamber of Commerce have developed anti-corruption policies and guidelines.

10) I. Carr (supra note 2) 121, 129.

11) Neither the travaux préparatoires nor the Legislative Guide fill this gap; see United Nations (ed.), Legislative Guide for the implementation of the United Nations Convention Against Corruption (New York 2006).

12) Arguing that courts have been following the doctrines of their municipal law is no defence to a breach of an international obligation; see E. Benvenisti, 'Judicial Misgivings Regarding the Application of International Law: An Analysis of Attitudes of National Courts', 4 European Journal for International Law (1993) 159, 160; A. Cassese, International Law, 2nd edition (Oxford 2005) 217-219; R.M.M. Wallace, International Law (London 1992) 36-37.

13) For the United Kingdom, see M.N. Shaw, International Law, 5th edition (Cambridge 2003) 140; R.M.M. Wallace, International Law, London 1992 36; Salomon v Commissioners of Customs and Exercise [1967] 2 QB 116, 143; for the US law, see I.A. Shearer, Starke's International Law, 11th edition (London 1994) 75; L. Brilmayer, 'International Law in American Courts: A Modest Proposal', 100 Yale Law Journal (1991), 2277, 2288-2289; US Supreme Court Whitney v Robertson 124 (1888) US 190, 194; for the German law, see the decision of the Federal Constitutional Court BVerfGE 111, 307, 316-319. For more details, see E. Denza, in: M.D. Evans (ed.), International Law (Oxford/New York 2003) 415, 432-433. 
Since some of these preceding conventions are accompanied by official commentaries or explanatory reports, they offer an indirect, yet deep insight into the UNCAC. The following remarks can hence invoke the credit of those international organizations whose legal instruments set the standards in the fight against corruption.

\section{Article 15: Bribery of National Public Officials}

\subsection{Scope and Significance of the Provision}

Article 15 comprises the hardcore form of corruption: bribery of national public officials. Bribery is the bestowing of a benefit in order to unduly influence an action or decision. ${ }^{14}$ Article 15 (a) covers "active bribery" criminalizing those who promise, offer or give directly or indirectly an undue advantage to a public official for himself or another person or entity, in order that the public official act or refrain from acting in the exercise of his duties. Article 15(b) covers "passive bribery" criminalizing the public official who solicits or accepts, directly or indirectly, an undue advantage, for himself or another person or entity, in order that the official act or refrain from acting in the exercise of his or her official duties. Similar articles can be found in a multitude of international conventions and other legal instruments. ${ }^{15}$ Of particular importance are the Council of Europe (CoE) Criminal Law Convention on Corruption, the OECD Convention on Bribery of Foreign Public Officials and the EU Convention on the Fight against Corruption since these instruments are accompanied by commentaries respectively explanatory reports which can be used to illuminate the scope of Article 15.

\subsection{The Terms}

\subsubsection{Public Official}

In order to comprehend the breadth of criminalization, Article 15 must be linked to Article 2 (a), since the latter defines the central figure in corruption affairs: the

\footnotetext{
14) United Nations Office on Drugs and Crime (ed.), 'The Global Programme Against Corruption' (Vienna 2004) 11.

15) Article 8 (1) United Nation Convention against Transnational Organized Crime; Articles VII, VI (1) Inter-American Convention Against Corruption; Articles 5 (1), 4 (1) African Union Convention on Preventing and Combating Corruption; Articles 2, 3 Council of Europe Criminal Law Convention on Corruption; Articles 2, 3 Protocol to the Convention on the protection of the European Communities' financial interests; Articles 2, 3 Convention drawn up on the basis of Article K.3 (2) (c) of the Treaty on the European Union on the fight against corruption involving officials of the European Communities or officials of the member states of the European Union; Article 1 International Chamber of Commerce Rules of Conduct and Recommendations to Combat Extortion and Bribery (addressing enterprises).
} 
public official. As the UNCAC seeks to cover all possible categories of public officials, it includes a wide definition that not only exceeds the range of many national criminal $\operatorname{codes}^{16}$ but also goes beyond the definition of other international conventions against corruption. ${ }^{17}$

According to Article 2 (a), the term "public official" encompasses any person holding a legislative, executive, administrative or judicial office whether appointed or elected and - even wider - any person performing a public function. Thus, the article covers public officials by appointment like policemen, customs officers, members of the armed forces, judges, public prosecutors and any other public servant. These "officials by status" fall within the range of Article 15 even if they currently do not exercise public functions but are in a position in which they will exercise such functions at a later time. Moreover, elected persons such as members of parliaments, mayors, or, where elected, public prosecutors or judges are subject to Article 15. Consequently, party states and its judiciary have to ensure that the standard of Article 15 equally applies to "casual" public officials and elected persons. Except from immunities (cf. Article 30 UNCAC), legal or judicial privileges for elected persons, for example special defences or restrictive interpretations of anti-bribery norms, are a violation of the UNCAC.

The scope of Article 2 (a), however, is even wider. Any person who performs a public function, for example a public agency or enterprise, or who provides a public service shall be considered as a public official irrespective of its status. The convention thereby reflects the fact that it is less the status but the function resulting in (potential) influence - that generates corruption. Therefore, courts have to assess thoroughly if a person who is not a public official by appointment works in a position in which he or she performs public functions or provides public services. "Public function" includes any activity in the public interest, delegated by the state to an individual or an entity. ${ }^{18} \mathrm{~A}$ national law or a contract which establishes specific rights or duties resembling those of a public official can be indicators that the function or service is performed in public interest. "Public Agency" is an entity constituted under public law to carry out specific tasks in the public interest. ${ }^{19} \mathrm{~A}$ "public enterprise" is any enterprise, regardless of its legal form, over which a government, or governments, may exercise a dominant influence. This can be the case, inter alia, when the government or governments hold the majority of the enterprise's subscribed capital, control the majority of votes

\footnotetext{
16) For a comparative overview cf. A. Eser, M. Kubiciel (supra note 1) 22-25.

17) See Article 1 (a) CoE Convention on Corruption; Article 1 (c) Council of the European Union Convention on the Fight against Corruption; comparable to the scope of Article 2 UNCAC are Article 1 (1) AU Convention on Preventing and Combating Corruption; Article 1 OAS InterAmerican Convention Against Corruption, and - concerning foreign public officials - Article 1 (4 a) OECD Convention on Combating Bribery.

18) Cf. for the comparable term in the OECD Convention OECD (ed.), Commentaries on the OECD Convention on Combating Bribery, note 12.

19) OECD (ed.), Commentaries on the OECD Convention on Combating Bribery, note 13.
} 
attaching to shares issued by the enterprise or can appoint a majority of the members of the enterprise's administrative or managerial body or supervisory board. ${ }^{20}$ Any official of a public enterprise shall be deemed to perform a public function unless the enterprise operates on a normal commercial basis in the relevant market, that is, under conditions which are substantially equivalent to that of private enterprises. ${ }^{21}$ According to that interpretation, persons working in a public enterprise that does not benefit from preferential subsidies or other legal or financial privileges are not public officials.

\subsubsection{Undue Advantage}

Bribery is a crime committed by rent-seeking individuals. ${ }^{22}$ The rent sought by the public official is called "undue advantage". With this term, the UNCAC has adopted a wide scope reflecting the fact that public proceedings and services can be perverted corruptively by all means which human beings regard as desirable. ${ }^{23}$

An "advantage" can be anything that places the public official or a third person in a better position than he or she was before the commission of the offence. ${ }^{24}$ In most cases the advantage is tangible and of value. Paradigmatic undue advantages are money, precious objects, holidays, food and drink and goods of all kinds. The convention however encompasses intangible items such as shares, rights or the remission of debts as well. ${ }^{25}$ Moreover, services or work rendered in favour of the public official or third persons are advantages criminalized by the convention. ${ }^{26}$ Finally, nepotism such as granting of a post, a career prospect or a political position is prohibited as bribery of national public officials. ${ }^{27}$

The term "undue" is inevitably vague. Nevertheless, national law-makers and law enforcement bodies may bear in mind two vertexes: On the one hand,

20) Cf. OECD (ed.), Commentaries on the OECD Convention on Combating Bribery, note 14.

21) Cf. OECD (ed.), Commentaries on the OECD Convention on Combating Bribery, note 15.

22) See A. Krueger, 'The Political Economy of the Rent-Seeking Society', 64 The American Economic Review (1974) 291. For rational rent-seeking as an axiom in economics, see D.E. Campbell, Incentives, 2nd edition (Cambridge 2006) 39.

23) Cf. A. Eser, M. Kubiciel (supra note 1) 41-42.

24) See CoE (ed.), ETS 173 Criminal Law Convention on Corruption and Explanatory Report (1999) 19.

25) Explanatory Report on the Convention on the fight against corruption involving officials of the European communities or officials of Member States of the European Union, Official Journal of the European Communities, C 391, 15.12.1998, at 4, note 2.4; 173 Criminal Law Convention on Corruption and Explanatory Report (1999) 19. Also see United Nations Office on Drugs and Crime (ed.), The Global Programme Against Corruption (Vienna 2004) 11-12.

26) Explanatory Report on the Convention on the fight against corruption involving officials of the European communities or officials of Member States of the European Union, O.J. C 391 15.12.1998, at 4, note 2.4. Also see United Nations Office on Drugs and Crime (supra note 25).

27) $C o E$ (ed.), ETS 173 Criminal Law Convention on Corruption and Explanatory Report (1999) 19. 
a public official is, as a general rule, remunerated by the state, its organs, institutions or enterprises. ${ }^{28}$ Thus, any advantage granted by a private person or entity to a public official ad personam implies the presumption of its undue character. On the other hand, those advantages whose acceptance is permitted or required by written law, regulation or case law are not criminalized. ${ }^{29}$ However, the blurring field on which corruption can strike roots lies between these vertexes. In order to root out corruption effectively, the EU Convention has adopted a strict regime by prohibiting any advantage whatsoever. ${ }^{30}$ States may wish to follow this example and interpret the term "undue advantage" of the UNCAC accordingly. This interpretation would solve the problem how to deal with advantages of very low value and socially accepted gifts by criminalizing them without any exception. The OECD Convention pursues the same direction as its Commentaries state that the offering, promising or giving of an advantage is an offence irrespective of the "perceptions of local costums". ${ }^{31}$ The Explanatory Report on the CoE Convention however acknowledges that "minimum gifts, gifts of very low value or socially acceptable gifts" are excluded from criminalization. ${ }^{32}$ The wording of the UNCAC is open for both the strict and the more flexible interpretation. Correspondingly, states can implement a minima non curat praetor-rule which exempts socially accepted advantages of a very low value from criminalization or adjudication. States, however, have to bear in mind that the line between an acceptable gift and corruption is thin. In any case, they have to ensure that the mere reference to a "tradition of gift" does not constitute a defence per se. Instead, courts have to evaluate carefully whether an alleged tradition exists and whether the behaviour matches the tradition. With regard to this, it has to be stressed that not any widespread behaviour can be called a tradition, since the latter implies the notion of social acceptance. For example, requesting "commissions" may be widespread in many African countries; behaviour of that kind, however, is not part of any country's "tradition". But even if the granting of an advantage is in line with an existing tradition, social contingencies of this kind must be subject to the evaluation whether they are capable of damaging the public confidence in the functioning of public services and state proceedings. Aspects like the value,

\footnotetext{
28) Ibid.

29) See CoE (ed.), ETS 173 Criminal Law Convention on Corruption and Explanatory Report (1999) 19; OECD (ed.), Commentaries on the OECD Convention on Combating Bribery, note 8. United Nations Office on Drugs and Crime (supra note 25) 11-12; Explanatory Report on the Convention on the fight against corruption involving offcials of the European communities or officials of Member States of the European Union, O.J. C 391 15.12.1998, at 4, note 2.4.

30) Cf. Artt. 2, 3 EU Convention.

31) OECD (ed.), Commentaries on the OECD Convention on Combating Bribery, note 7.

32) See CoE (ed.), ETS 173 Criminal Law Convention on Corruption and Explanatory Report (1999) 19. United Nations Office on Drugs and Crime (supra note 25); Explanatory Report on the Convention on the fight against corruption involving officials of the European communities or officials of Member States of the European Union, O.J. C 391, 15.12.1998, at 4, note 2.4.
} 
the frequency, the temporal closeness to an official act, the lack of transparency, the failure to disclose or register can serve as evidence for the "undue" character. Other features states may consider as indicators for bribery are the secrecy of the granting and the usage of intermediaries, both typical patterns of corruptive behaviour.

\subsubsection{Promise, Offering or Giving}

The convention provides for a comprehensive criminalization of active bribery as Article 15 (a) covers all stages from promising, offering to giving as mandatory provisions.

The term "promise" indicates the relevant intention to bribe, whether or not the donor has the resources to provide the undue advantage or actually intends to hand over the bribe. Promising may, for example, cover situations where the briber undertakes to give an undue advantage later or where there is an agreement between the briber and the bribe taker to grant the bribe in the future, even after the public official has acted or has refrained from acting in the exercise of his duties. ${ }^{33}$ "Offering" inherently encompasses the signalization of readiness by the active briber to give the undue advantage at any moment. ${ }^{34}$ The conduct described is an offence whether or not the promise or offer is made on that person's own behalf or on behalf of any other natural person or legal entity. ${ }^{35}$ The term "giving" covers the transfer or granting of the undue advantage. ${ }^{36}$ "Giving" does not require a physical handover. Rather, the term includes, for example, a bank transaction that results in a credit item on a bank account the official has at his disposal. States and their law enforcement bodies may bear in mind that said corrupt manoeuvres can be either unilateral or bilateral, ${ }^{37}$ so that offering, promising or giving is to be penalized irrespective of the existence of an agreement between briber and bribee. Consequently, states whose statutory law or case law require the proof of an "corruption pact" or another form of mutual agreement between the briber and the public official fall short of the standard set by the UNCAC. ${ }^{38}$

\subsubsection{The Solicitation or Acceptance}

These terms refer to the criminalized behaviour of passive bribery. "Solicitation" means a unilateral act of, explicitly or implicitly, letting a person know that an

\footnotetext{
33) See CoE (ed.), ETS 173 Criminal Law Convention on Corruption and Explanatory Report (1999) 18.

34) Ibid.

35) OECD (ed.), Commentaries on the OECD Convention on Combating Bribery, note 6.

36) See CoE (ed.), ETS 173 Criminal Law Convention on Corruption and Explanatory Report (1999) 19.

37) Explanatory Report on the Convention on the fight against corruption involving officials of the European communities or officials of Member States of the European Union, O. J. C 391, 15.12.1998, at 5 , note 3.2 .

38) For examples, cf. A. Eser, M. Kubiciel (supra note 1) 28-30.
} 
advantage has to be granted to have an official act done or abstained from being done. ${ }^{39}$ States should consider that it is irrelevant whether the solicitation is acted on or not, for the request itself being the core of the offence. ${ }^{40}$ "Acceptance" can be understood as the actual receipt of the undue advantage. Receiving may hence mean the virtual take-over by the public official or a third person. ${ }^{41}$ The term requires that the bribe has been situated in the sphere of the public official, his intermediary or the third person profiting from the bribe. Thus, national law enforcement bodies may regard it as sufficient that a payment has been booked on a bank account of the profiting person or that the bribe has been left in a bank deposit to which the profiting person has access. The Explanatory Report on the $\mathrm{CoE}$ Convention states that receiping shall be interpreted as keeping the advantage at least for some time so that the official, who having not requested it, immediately returns the advantage to the sender would not be committing an offence. ${ }^{42}$ Contrary to that, the Commentary to the EU Convention clarifies that the offence is committed even if the official returns the thing received. ${ }^{43}$ States should follow the latter interpretation since the term "acceptance" is wider than the term "receipt" as it includes the mere consent to a forthcoming receipt of an undue advantage. ${ }^{44}$ According to this interpretation, the offence is complete when consents have been exchanged, even if the official subsequently waives the performance of the agreement. ${ }^{45}$ Consequently, the point in time at which the undue advantage is given or provided for is immaterial. By expressively covering the acceptance of promises, this paragraph criminalizes deferred payments, provided their origin lies in a criminal agreement between the briber and the public official. ${ }^{46}$

\footnotetext{
39) See Explanatory Report on the Convention on the fight against corruption involving officials of the European communities or officials of Member States of the European Union, O. J. C 391, 15.12.1998, at 4, note 2.2; CoE (ed.), ETS 173 Criminal Law Convention on Corruption and Explanatory Report (1999) 19.

40) See Explanatory Report on the Convention on the fight against corruption involving officials of the European communities or officials of Member States of the European Union, O.J. C 391, 15.12.1998, at 4 , note 2.2 .

41) See CoE (ed.), ETS 173 Criminal Law Convention on Corruption and Explanatory Report (1999) 19.

42) $\operatorname{CoE}$ (ed.), ETS 173 Criminal Law Convention on Corruption and Explanatory Report (1999) 20.

43) See Explanatory Report on the Convention on the fight against corruption involving officials of the European communities or officials of Member States of the European Union, O.J. C 391, 15.12.1998, at 4 , note 2.2 .

44) Cf. Explanatory Report on the Convention on the fight against corruption involving officials of the European communities or officials of Member States of the European Union, O.J. C 391, 15.12.1998, at 4 , note 2.2 .

45) Ibid.

46) Ibid.
} 


\subsubsection{Directly or Indirectly}

The article criminalizes the promising, offering, giving, soliciting and accepting of an undue advantage both in a direct or indirect manner. Therefore, bribers cannot circumvent punishment by using intermediaries neither on the active nor the passive side. The wording ("directly or indirectly") as well as the ratio legis closing legal loopholes - suggest that it is irrelevant, whether the intermediary is a person or a legal entity. It has to be stressed that these intermediaries may not necessarily be participators in crime such as accomplices, assistants or instigators mentioned by Article 27. For that reason, it is immaterial whether the intermediary has acted in good or bad faith. ${ }^{47}$

\subsubsection{For Himself or Herself or Another Person or Entity}

The criminal core of bribery is not the transfer of properties, but rather the abuse of public office for private benefit. ${ }^{48}$ It thus is of minor importance whose private interests are being served and who is the beneficiary of the bribe. Article 15 consequently provides for a comprehensive range of beneficiaries of the undue advantages: It encompasses all cases in which another person, for example a relative or a friend of the public official, receives or shall receive the advantage, either indirectly through the public official or directly with the knowledge of the public official. Apart from (natural) persons, entities can be the beneficiary of the advantage. States and law enforcement agencies should take into account that the meaning of "entity" is wider than the notion "legal person". ${ }^{49}$ The provision hence covers, for example, charities, political parties and other entities, irrespective of their status as legal person according to the national law. The Explanatory Report on the CoE Conventions states that the public official must be a member of the party or organization which profits from the bribe..$^{50}$ Accordingly, the criminal law would not cover cases in which a public official accepts an undue advantage in favour of a political party without being a formal member of this party or after having cancelled the membership. Consequently, the Commentary on the EU Convention does not contain such a restriction..$^{51}$ As far as the UNCAC is

47) CoE (ed.), ETS 173 Criminal Law Convention on Corruption and Explanatory Report (1999) 19; Explanatory Report on the Convention on the fight against corruption involving officials of the European communities or officials of Member States of the European Union, O.J. C 391, 15.12.1998, at 4 , note 2.2 .

48) See A. Doig, R. Theobald (supra note 1) 3; V. Tanzi (supra note 1) 564.

49) Cf. Article 1 lit. d CoE Criminal Law Convention On Corruption and Article 1 of the Council Framework Decision 2003/568/JHA of 22 July 2003 on combating corruption in the private sector, O.J. L 192/54, 31.7.2003, which distinguish a legal person from an entity, ascribing a wider scope to the latter.

50) CoE (ed.), ETS 173 Criminal Law Convention on Corruption and Explanatory Report (1999) 19.

51) See Explanatory Report on the Convention on the fight against corruption involving officials of the European communities or officials of Member States of the European Union, O.J. C 391, 15.12.1998, at 4 , note 2.3 . 
concerned, states may take into account that the wording of Article 15 does not suggest the said restriction so that they should pursue the aim of the convention and its articles: draining legal lacunas.

\subsubsection{In Order to Act or Refrain from Acting in the Exercise of His or Her Official Duty}

This phrase specifies that the article does not apply to gifts or other undue advantages that are not related to any subsequent act by the official in the performance of his official duties. ${ }^{52}$ On the other hand, Article 15 does not require that the act or omission has actually taken place. In fact, it is sufficient that the undue advantage is promised or solicited in order that the public official - in the future - acts or refrains from acting. Moreover, the term "in order to act or refrain from acting" reveals that not the actual outcome is the key to the offence, but the intended transaction. It is therefore irrelevant, whether the public official is actually able or willing to perform the official act or to refrain from acting. States should consider that the said element of crime does not require law enforcement bodies to proof a connection between the giving of a bribe and a concrete act or omission. For this reason, the notorious granting of undue advantages with respect to a future act or omission, not substantiated yet, has to be criminalized.

As the wording "in order to" implies a future act or omission by the official, the article does not encompass the situation in which an undue advantage is given or accepted after the act or omission of the public official without a prior offer, promise or solicitation, unless the offer or promise continues in effect in relation to future acts or omissions of the public official. ${ }^{53}$ Nevertheless, states may consider implementing legislation extending criminalization on such cases. ${ }^{54}$

Moreover, states should consider that the UNCAC - in contrast to Article 3 EU Convention - does not require that the promised or actually performed act or omission constitutes or would constitute a breach of duty. The decisive element of the offence is not whether the official had any discretion to act as requested by the briber, but whether he had been offered, given or promised an undue advantage in order to obtain something from him. ${ }^{55}$ Accordingly, the exchange of a bribe to obtain an act which the public official is legally entitled or required to perform is covered by the criminalization as bribery of public official.

\footnotetext{
52) See Explanatory Report on the Convention on the fight against corruption involving officials of the European communities or officials of Member States of the European Union, O.J. C 391, 15.12.1998, at 5 , note 2.5 .

53) See Explanatory Report on the Convention on the fight against corruption involving officials of the European communities or officials of Member States of the European Union, O.J. C 391, 15.12.1998, at 5, note 2.5; ETS 173 Criminal Law Convention on Corruption and Explanatory Report (1999) 20.

54) For examples, see A. Eser, M. Kubiciel (supra note 1) 30.

55) $\operatorname{CoE}$ (ed.), ETS 173 Criminal Law Convention on Corruption and Explanatory Report (1999) 19.
} 
In order to assure compliance with Article 15, states whose bribery provisions require a breach of duty have to amend their law accordingly. Another possibility to comply with the convention would be an interpretation of such clauses according to which the mere connection between an undue advantage and the public act or omission constitutes a breach of duty.

Finally, the term "in the exercise of his or her official duty" does not only cover public officials acting within the competencies and functions assigned to them. ${ }^{56}$ In fact, the systematic connection to the phrase "in order to act or refrain from acting" suggests that the article encompasses officials who pretend to act in an official capacity for the purpose of bribery. Thus, an off-duty police officer wearing his/her uniform to solicit bribes from drivers can be bribed and can commit passive bribery as well as the tax collector who pretends to be capable to remit taxes for the future although he is not able or entitled to do so.

\section{Article 16 (1): Active Bribery of Foreign Public Officials and Officials of Public International Organizations}

\subsection{Scope and Significance of the Provision}

Article 16 (1) transfers the provision on bribery of public officials to the transnational and international level thereby reflecting that the global economic and political development in recent decades has also energized the export of economic crime. In particular, corruptive behaviour has become an increasing problem of world trade that disturbs international competition and has proven to be a major obstacle for the economic and social development in many countries of the southern hemisphere. ${ }^{57}$ Combating transnational corruption however is more than an altruistic act to promote social development abroad. It rather lies in the rational interest of any developed state since a mentality of corruption, once established, negatively affects the standards of behaviour in business transactions and public proceedings at home. Since the fight against national corruption can only be won by creating a mentality that rejects corruption unconditionally, states should set common legal standards for both national and international business. As the criminal law articles of several conventions show, this call has been heard. ${ }^{58}$

56) CoE (ed.), ETS 173 Criminal Law Convention on Corruption and Explanatory Report (1999) 19. For the interpretation of the differently drafted Article 5 EU Convention, see Explanatory Report on the Convention on the fight against corruption involving officials of the European communities or officials of Member States of the European Union, O.J. C 391, 15.12.1998, at 5, note 2.6.

57) A. Doig, R. Theobald (supra note 1) 8-9; R. Sandbrook, J. Oelbaum, 'Reforming Dysfunctional Institutions through Democratization?', 35 Journal of Modern African Studies (1997) 603, 605, 628.

58) Article 8 (2) UN Convention Against Transnational Organized Crime; Article 1 OECD Convention on Combating Bribery of Foreign Public Officials in International Business 
In addition, Article 16 (1) criminalizes the active bribery of officials of public international organizations. It thereby closes legal loopholes which may exist in criminal codes whose anti-bribery provisions only cover national and foreign public officials. Safeguarding the impartiality of decision-making in international organizations is of growing importance since these institutions are major financers of projects and contractors in international business. Consequently, Article 16 (1) is an important tool to protect the financial interests of international organizations and their member states. Besides, the penalization safeguards the impartiality of procurement procedures and the bidders' chances of success. Finally, corruption in international organizations endangers the success of their programmes, many of them providing help for poor and under-developed countries. Accordingly, several legal instruments apart from the UNCAC criminalize active bribery of officials of public international organisations. ${ }^{59}$

\subsection{The Terms}

Generally speaking, Article 16 (1) mirrors the provision on active bribery of national public officials as mentioned by Article 15 (a). While both articles largely include identical elements of crime, states should pay particular attention to a significant difference: Article 16 (1) solely criminalizes those acts of transnational and international bribery that are performed in order to obtain or retain business or other undue advantage in relation to the conduct of international business. The subsequent analysis focuses on the particularities of Article 16 (1). In addition, the remarks made on Article 15 apply mutatis mutandis.

\subsubsection{Foreign Public Offcial - Offcial of a Public International Organization}

Again, the full range of Article 16 (1) can only be understood properly when considering the definitions laid down in Article 2.

The convention has opted for a broad criminalization which encompasses both public officials by status and those by function: According to Article 2 (b) a "foreign public official" is not only any person holding a legislative, executive, administrative or judicial office of a foreign country, whether appointed or elected, but also any person exercising a public function for a foreign country, including those

\footnotetext{
Transactions; Article 3 EU Convention on the fight against corruption involving officials of the European Communities or officials of the member states; Article 5 Council of Europe Criminal Law Convention on Corruption; Art VIII Inter-American Convention against Corruption; Article 1 International Chamber of Commerce Rules of Conduct and Recommendations to Combat Extortion and Bribery.

59) Article 8 (2) UN Convention Against Transnational Organized Crime; Article 1 OECD Convention on Combating Bribery of Foreign Public Officials in International Business Transactions; Article 5 Council of Europe Criminal Law Convention on Corruption; Article 3 EU Convention on the fight against corruption involving officials of the European Communities or officials of the member states.
} 
working for a public agency or public enterprise. States may consider that Article 2 suggests an autonomous definition. Consequently, the evaluation whether a person is a foreign public official is not necessarily linked to the status of the person according to the law of the foreign state. Thus, courts may conclude that a person indeed is a foreign public official according to the UNCAC although the foreign law has a different perception. Moreover, states should take into account that the definition covers public officials of any foreign country, including nonparty states. ${ }^{60}$ Finally, the term "foreign country" is broader than the term "foreign state"; it hence covers any organized foreign area or entity, such as an autonomous territory or a separate customs territory. ${ }^{61}$

According to Article 2 (c), "official of a public international organization" shall mean an international civil servant or any person who is authorized by such an organization to act on behalf of that organization. The term "public international organization" includes any international organization formed by states, governments, or other public international organizations, whatever its form and scope of tasks may be. ${ }^{62}$ On the other hand, international organizations which are organized and financed by private persons or entities are not covered by the article. It is not necessary under the convention that the state party is a member of the international organization in which the corruptive act has been committed. ${ }^{63}$ While the UNCAC speaks of public "international" organizations, states may bear in mind that the article also covers civil servants working for those international organizations which have already reached a degree of political integration that would suggest the term "supranational" organization. ${ }^{64}$ Finally, states should consider that the term "official of a public international organization" does not only encompass permanent or temporal international civil servants, for example those covered by the staff or employment regulation of the organization. Besides, the provision includes any other person authorized by the organization to act on behalf of it. Thus, the article encompasses persons seconded to member states to the organization or persons engaged on contract with the authorization to act on behalf of the organization. ${ }^{65}$

60) Cf. CoE (ed.), ETS 173 Criminal Law Convention on Corruption and Explanatory Report (1999) 21, note 49.

61) OECD (ed.), Commentaries on the OECD Convention on Combating Bribery, note 18.

62) OECD (ed.), Commentaries on the OECD Convention on Combating Bribery, note 17.

63) See United Nations (ed.), Legislative Guide for the implementation of the United Nations Convention Against Corruption (New York 2006), note 206. Contrary to that, Article $9 \mathrm{CoE}$ Criminal Law Convention on Corruption solely covers international organizations "of which the Party is a member".

64) Cf. OECD (ed.), Commentaries on the OECD Convention on Combating Bribery, note 17; Article $9 \mathrm{CoE}$ Criminal Law Convention on Corruption mentions both international and supranational organizations.

65) CoE (ed.), ETS 173 Criminal Law Convention on Corruption and Explanatory Report, 23, note 59 . 


\subsubsection{Undue Advantage}

The interpretation of the term "undue advantage" is even more complicated when national courts and law enforcement agencies have to evaluate whether an advantage offered or granted abroad is undue or not. Generally speaking, courts can apply the standards of their own legal order, so that they are not bound to the perceptions abroad. Thus, local traditions or the tolerance by foreign authorities are no excuse per se for offering or giving advantages to foreign public officials or officials of international organizations. ${ }^{66}$ However, advantages whose acceptance is permitted or even required by the foreign law are not criminalized by Article $16 .{ }^{67}$

\subsubsection{In Order to Obtain or Retain Business or Other Undue Advantage in Relation to the Conduct of International Business}

Article 16 (1) exclusively covers advantages used in order to obtain or retain business or other undue advantage in relation to the conduct of international business. Consequently, the UNCAC has not adopted the wide range of the $\mathrm{CoE}$ Convention which criminalizes foreign bribery irrespective of the context in which the corruptive act takes place, ${ }^{68}$ but rather follows the narrow understanding of the OECD Convention. Thus, Article 16 (1) does not criminalize acts of bribery committed for mere private purposes. Payments, for example, which are granted by tourists to foreign public officials in order to facilitate the entry to the country are not covered by the article. The term "business" however is to be interpreted in a broad sense, encompassing any kind of commercial activity such as trading in goods and delivering services. ${ }^{69}$ The term does not require the proof that the advantage is given in order to make profit. Thus, states may penalize cases of bribery in which no immediate profit is thinkable.

Of great importance is the question whether this phrase provides the opportunity to exclude the notorious cases of "facilitation payments". Facilitation payments are made for routine governmental action, such as processing papers, issuing permits, and other actions of an official, in order to expedite performance of duties of non-discretionary nature, i.e., which they are already bound to perform. Such forms of "grease payments" are not intended to influence the outcome of the official's action, only its timing. ${ }^{70}$ The Commentaries on the OECD

66) $O E C D$ (ed.), Commentaries on the OECD Convention on Combating Bribery, note 7.

67) $O E C D$ (ed.), Commentaries on the OECD Convention on Combating Bribery, note 8.

68) Cf. CoE (ed.), ETS 173 Criminal Law Convention on Corruption and Explanatory Report, 1999, 21, note 49 .

69) Including services to the public, cf. CoE (ed.), ETS 173 Criminal Law Convention on Corruption and Explanatory Report (1999) 21, note 53.

70) For the relevant rule in US law, see $\$ \$ 78 \mathrm{dd}-1$ (b), (f) (3) FCPA. Also see S. H. Deming, The Foreign Corrupt Practices Act And the New International Norms (Chicago 2005) 15; R. Bailes, 'Facilitation Payments: Culturally Acceptable or Unacceptable Corrupt?' 15 Business Ethics: 
Convention suggest that these payments do not constitute advantages made to obtain or retain business or other improper advantage and, therefore, are not a criminal offence under the OECD Convention. ${ }^{71}$ The reason for this exemption lies in the fact that the OECD Convention primarily tackles corruption as a distortion of free competition. As small facilitation payments do not impede free trade they are not covered by the ratio legis of the OECD Convention. States which follow the interpretation of the OECD may abstain from criminalizing cases in which grease payments are paid to hasten the completion of a non-discretionary routine action. However, the wording of the UNCAC does not require such a wide exemption from criminalization. Rather, the facilitation of proceedings can be conceived as an "other advantage in relation to the conduct of international business". More importantly, the aim of the UNCAC suggests a comprehensive penalization of bribery, including grease payments: Unlike the OECD Convention, the UNCAC does not focus on corruption as an obstacle for fair and free trade. Rather, the preamble of the UNCAC stresses "the seriousness of problems and threats posed by corruption to the stability and security of societies, undermining the institutions and values of democracy, ethical values and justice and jeopardizing sustainable development and the rule of law". As facilitation payments can be a first move in a game that leads to grand corruption and since all forms of bribery can, in the long run, affect institutions and legal values, ${ }^{72}$ states should, as a general rule, criminalize facilitation bribes. Law enforcement bodies may, however, abstain from adjudicating cases of marginal gifts in application of the minima non curat praetor-rule, for example, when the perpetrator has not committed a comparable crime before or the enterprise establishes safeguards that impede facilitation payments in the future.

\section{Conclusion}

With the adoption of the UNCAC in 2003, the international legal development in the fight against corruption has reached its peak. Now the convention has to be filled with life. This is the task of national law-makers, law enforcement bodies and courts. They all need substantial information concerning the content of the convention's articles. This study provides the necessary information for the core criminal law provisions - bribery of public official and active bribery of foreign

A European Review, (2006) 293, 295; A. Argandoña, Corruption and Companies: The Use of Facilitating Payments', 60 Journal of Business Ethics (2005) 251, 253-254.

71) OECD (ed.), Commentaries on the OECD Convention on Combating Bribery, note 9. According to the authors of the commentary, the criminalization of such payments does not seem "practical or effective".

72) A. Argandoña (supra note 70) 252, 257-258; R. Bailes (supra note 70) 297. 
public officials - by means of relating to preceding conventions and their commentaries and explanatory reports. This may compensate the lack of an official commentary to the UNCAC. However, legal transplants alone do not cure social diseases such as corruption. Since there is no "hydraulic relationship" between criminal law and human behaviour, ${ }^{73}$ even the strictest implementation of the convention cannot guarantee the transformation of international legal standards into social reality. A civic spirit of virtue as "mental software" is needed to drive the hardware of the new laws. ${ }^{74}$ Consequently, the core criminal law provisions of the UNCAC can only be instruments among others. Nevertheless, they have to be used with expertise.

73) A. Ashworth, Principles of Criminal Law, 5th edition (Oxford 2006) 16.

74) C. Offe, 'Cultural Aspects of Consolidation: A Note on the Peculiarities of Postcommunist Transformation', 6 East European Constitutional Review (1997) 64, 67. 